\section{Factors associated with the severity of pruritus in patients with terminal chronic kidney disease under- going hemodialysis in Lima, Peru}

\author{
Stefano Kossuth-Cabrejos, ${ }^{1}$ \\ Arquímedes M. Gavino-Gutiérrez, ${ }^{2}$ \\ Wilmer Silva-Caso ${ }^{3,4}$ \\ ${ }^{1}$ Dermatologist, Universidad Nacional \\ Mayor de San Marcos; ${ }^{2}$ Faculty of \\ Health Sciences, Universidad Peruana \\ de Ciencias Aplicadas (UPC); ${ }^{3}$ Research \\ and Innovation Centre of the Faculty of \\ Health Sciences, Universidad Peruana \\ de Ciencias Aplicadas (UPC); ${ }^{4}$ Facultad \\ de Ciencias de la Salud, Universidad \\ Tecnológica del Perú, Lima, Peru
}

\begin{abstract}
The objective of the study is to analyze the factors associated with the severity of pruritus in patients with terminal chronic kidney disease undergoing hemodialysis.

The methodology used is based on a cross-sectional study in patients receiving hemodialysis at the Centro Nacional de Salud Renal. Severe pruritus was defined as a score on the visual analogue scale greater than or equal to 7, and the strength of association with the possible risk factors was assessed by calculating prevalence ratios. Regarding the results, 264 patients were included, $59.9 \%$ were male, with a mean time on hemodialysis of $10.26 \pm 7.14$ years. $75 \%$ experienced pruritus, of this group, 1 in 3 presented severe pruritus. Hyperphosphatemia and the use of antihistamines were associated with a higher prevalence of severe pruritus (RP 1.71, 95\% CI $1.09-267$ and RP $2.39,95 \%$ CI 1.51-3.75, respectively). The positive serology for Hepatitis C Virus was described as a protective factor for presenting severe pruritus (RP $0.55,95 \%$ CI 0.33 - 0.89). In conclusion, severe uremic pruritus is a frequent problem in patients with chronic terminal kidney disease who have hyperphosphatemia and treatment with antihistamines independently of the time they have been on hemodialysis.
\end{abstract}

\section{Introduction}

End-Stage Renal Disease is the final stage of Chronic Kidney Disease (CKD) and its incidence has increased considerably in the last 30 years. $^{1-3}$ The pruritus is defined as an unpleasant and subjective sensation that forces the individual to scratch, it may be localized or generalized, and is a frequent symptom in patients with terminal chronic kidney disease on hemodialysis; ${ }^{4-7}$ it is the most reported dermatological symptom, with a prevalence ranging between 20 and $90 \%$, and, also, it significantly affects the quality of life, the adherence the treatment and the management of associated comorbidities. ${ }^{8,9}$

The pathophysiology of pruritus in patients with terminal chronic kidney disease is not well understood, however, a series of studies have described several factors that could influence the pathogenesis of the problem, including, BUN, serum calcium and phosphorus levels, high Parathyroid Hormone (PTH) levels, a compromised skin barrier, the dose of dialysis (kt/ V), the type of membrane used by the dialysis equipment, among others. ${ }^{6,9-12}$ Perhaps the most relevant study, which managed to establish the factors associated with pruritus in patients with chronic kidney disease on hemodialysis was the Daily Outcomes and Practice Patterns Study (DOPPS); it was a cohort of 18801 patients on hemodialysis from 12 different countries and it was determined that male patients, lung disease, congestive heart failure, high phosphorus and calcium levels, and low albumin levels, experienced pruritus more severe than the controls. They also established that there was a slight increase in the severity of pruritus in the first 10 years of illness. ${ }^{8}$ In Peru, according to the Reporte del Registro Nacional de Diálisis (RENDES) for 2015, an average of 27391 patients with terminal chronic kidney disease are undergoing dyalisis. ${ }^{13}$ In this context, few studies have evaluated the presence and factors associated with the severity of pruritus in these patients. For this reason, it is necessary to perform an investigation that can determine the factors associated with the presence and severity of pruritus in the peruvian population undergoing hemodialysis.

\section{Materials and Methods}

\section{Type of Research and design}

Analytical cross-sectional study in patients receiving hemodialysis from the Centro Nacional de Salud Renal (CNSR).

\section{Population}

The study population included 282 patients with terminal chronic kidney disease on hemodialysis treated at the Centro Nacional de Salud Renal (CNSR), registered in July 2017, of whom 264 agreed to
Correspondence: Wilmer Gianfranco Silva Caso, Research and Innovation Centre of the Faculty of Health Sciences, Universidad Peruana de Ciencias (UPC), Av. Primavera 2390-Monterrico, Lima, Peru.

Tel.: +51 1992154452 - Fax: +51 012470111 E-mail: gian_will@hotmail.com

Key words: Pruritus; Dialysis; Chronic Renal Failure.

Conflict of interest: The authors declare no potential conflict of interests.

Ethical approval: The study was approved by the Ethics Committee of the Hospital Nacional Edgardo Rebagliati Martins and by the Research Committee of the Centro Nacional de Salud Renal (CNSR).

Received for publication: 17 September 2019. Accepted for publication: 25 May 2020

This work is licensed under a Creative Commons Attribution-NonCommercial 4.0 International License (CC BY-NC 4.0).

(C) Copyright: the Author(s), 2020

Licensee PAGEPress, Italy

Dermatology Reports 2020; 12:8310

doi:10.4081/dr.2020.8310

participate in the study. Minors and individuals with a history of a previous dermatological condition were excluded, as were those who did not give informed consent.

\section{Data Collection}

A survey was developed that included the age and sex of the patient, the time on hemodialysis, and the Visual Analogue Scale (VAS) for pruritus which determines that an itch is severe when the score obtained is greater than or equal to $7 .{ }^{14}$ This survey was applied during the months of July and August of 2017. The rest of the variables were obtained directly from the database of the Centro Nacional de Salud Renal (CNSR) through a data collection sheet.

\section{Processing and Data Analysis}

The population was described using measures of central tendency (mean and median), distribution (Standard Deviation, $\mathrm{SD}$ ), and Interquartile Range (IQR) for numeric variables. For the categorical variables, the frequencies and percentages were reported. Next, a bivariate analysis was conducted using chi-squared and Fisher's exact tests for the corresponding categorical variables, and the significance level was set at $\mathrm{p}<0.05$. The crude and adjusted Prevalence Ratio (PR) values were calculated with their respective confidence intervals 
using Poisson regression analysis with robust error variance.

\section{Ethical aspects}

The study was approved by the Ethics Committee of the Hospital Nacional Edgardo Rebagliati Martins and by the Research Committee of the Centro Nacional de Salud Renal (CNSR). In addition, subjects had to sign a consent form in order to ensure the anonymity of the study and to secure the management of personal information.

\section{Results}

264 individuals were recruited to participate in the study. Regarding their clinical profile, most patients were male $(59.9 \%)$, with an average age of $52.17 \pm 15.32$ years. Likewise, the mean time of hemodialysis was $10.26 \pm 7.14$ years. Furthermore, $73.9 \%(195 / 264)$ of the individuals reported pruritus at the time of the study (Table 1).

In relation to the characteristics of the patients who suffered pruritus, the average score on the visual analog scale was $5.56 \pm$
2.3, and, according to the cut-off point proposed in the study, 1 in 3 experienced severe itching. Additionally, it was determined that 81 patients who had pruritus symptom presented positive serology for Hepatitis C Virus. Regarding calcium and phosphorus values, $27.1 \%$ and $37.2 \%$ presented hypercalcemia and hyperphosphatemia respectively. On the other hand, almost 1 in 4 patients suffered from anemia, and with respect to the use of medications, $4.1 \%$ of patients used Gabapentin and $49.2 \%$ antihistamines to control their pruritus (Table 2). Table 3 shows the results of the bivariate analysis. It established that high serum phosphorus levels, the dose of dialysis, the use of gabapentin and the use

Table 1. Characteristics of patients with end-stage renal disease $(n=264)$.

\begin{tabular}{llc} 
& & n (\%) \\
Age & Mean (SD) & $52.17(15.32)$ \\
Gender & Male & $158(59.9)$ \\
& Female & $106(40.1)$ \\
\hline Time in dialysis & Mean (SD) & $10.26(7.14)$ \\
Pruritus & Yes & $195(73.9)$ \\
& No & $69(26.1)$ \\
\hline
\end{tabular}

Table 2. Dialysis dose, pruritus intensity and electrolyte values of patients with itching $(\mathbf{n}=195)$.

\begin{tabular}{llc} 
& & n (\%) \\
Hypercalcemia & Yes & $51(27.1)$ \\
& No & $137(72.9)$ \\
Hyperphosphatemia & Yes & $68(35.8)$ \\
& No & $122(64.2)$ \\
\hline Hypoalbuminemia & Yes & $70(37.2)$ \\
& No & $118(62.8)$ \\
Excess of Ferritin & Yes & $184(95.3)$ \\
& No & $9(4.7)$ \\
\hline Score (VAS) & Mean (SD) & $5.56(2.29)$ \\
Itching (Intensity) & Severe & $68(34.9)$ \\
(n=195) & Non severe & $127(65.1)$ \\
\hline Anemia & Yes & $46(23.6)$ \\
& No & $149(76.4)$ \\
Dialysis dose & kt $N$ low & $33(18.1)$ \\
& $(<1,3)$ & $149(81.9)$ \\
& kt $N$ & \\
& conventional & \\
& $(\geq 1,3)$ & \\
\hline Use of gabapentin & Yes & $8(4.1)$ \\
& No & $187(95.9)$ \\
Use of antihistamines & Yes & $96(49.2)$ \\
& No & $99(50.8)$ \\
\hline Hepatitis C & Yes & $81(41.5)$ \\
CRP (mg/dL) & No & $114(58.5)$ \\
\hline Some numbers may not add up due to missing values.
\end{tabular}

Table 3. Association between the characteristics and the severity of pruritus.

\begin{tabular}{|c|c|c|c|c|c|c|}
\hline \multicolumn{2}{|c|}{$\begin{array}{l}\text { Characteristics of patients with terminal } \\
\text { chronic kidney disease }\end{array}$} & \multicolumn{4}{|c|}{ Pruritus patients (n=195) } & p value \\
\hline Age & Mean (SD) & 53.07 & 15.23 & 52.18 & 15.12 & $0.69 *$ \\
\hline Gender & $\begin{array}{l}\text { Male } \\
\text { Female }\end{array}$ & $\begin{array}{l}45 \\
23\end{array}$ & $\begin{array}{l}66.2 \\
33.8\end{array}$ & $\begin{array}{l}76 \\
51\end{array}$ & $\begin{array}{l}59.8 \\
40.2\end{array}$ & $0.39 * *$ \\
\hline Hepatitis C serology & $\begin{array}{l}\text { Yes } \\
\text { No }\end{array}$ & $\begin{array}{l}19 \\
49\end{array}$ & $\begin{array}{l}27.9 \\
72.1\end{array}$ & $\begin{array}{l}62 \\
65\end{array}$ & $\begin{array}{l}48.8 \\
51.2\end{array}$ & $0.005^{* *}$ \\
\hline Dialysis time & Mean (SD) & 10.54 & 6.59 & 11.04 & 7.62 & $0.65^{*}$ \\
\hline Dialysis dose & $\begin{array}{l}\mathrm{kt} / \mathrm{N} \text { low }(<1,3) \\
\mathrm{kt} / \mathrm{N} \text { conventional }(\geq 1,3)\end{array}$ & $\begin{array}{l}17 \\
46\end{array}$ & $\begin{array}{l}27.0 \\
73.0\end{array}$ & $\begin{array}{c}16 \\
103\end{array}$ & $\begin{array}{l}13.4 \\
86.6\end{array}$ & $0.02 * *$ \\
\hline Laboratory charac & & & & & & \\
\hline Anemia & $\begin{array}{l}\text { Yes } \\
\text { No }\end{array}$ & $\begin{array}{l}15 \\
53\end{array}$ & $\begin{array}{l}22.1 \\
77.9\end{array}$ & $\begin{array}{l}31 \\
96\end{array}$ & $\begin{array}{l}24.4 \\
75.6\end{array}$ & $0.71^{* *}$ \\
\hline Hypercalcemia & $\begin{array}{l}\text { Yes } \\
\text { No }\end{array}$ & $\begin{array}{l}20 \\
47\end{array}$ & $\begin{array}{l}29.8 \\
70.2\end{array}$ & $\begin{array}{l}31 \\
90\end{array}$ & $\begin{array}{l}25.6 \\
74.4\end{array}$ & $0.53^{* *}$ \\
\hline Hyperphosphatemia & $\begin{array}{l}\text { Yes } \\
\text { No }\end{array}$ & $\begin{array}{l}33 \\
35\end{array}$ & $\begin{array}{l}48.5 \\
51.5\end{array}$ & $\begin{array}{l}35 \\
87\end{array}$ & $\begin{array}{l}28.7 \\
71.3\end{array}$ & $0.006^{* *}$ \\
\hline Hypoalbuminemia & $\begin{array}{l}\text { Yes } \\
\text { No }\end{array}$ & $\begin{array}{l}25 \\
43 \\
\end{array}$ & $\begin{array}{l}36.8 \\
63.2\end{array}$ & $\begin{array}{l}45 \\
75 \\
\end{array}$ & $\begin{array}{l}37.5 \\
62.5\end{array}$ & $0.92^{* *}$ \\
\hline Excess of Ferritin & $\begin{array}{l}\text { Yes } \\
\text { No }\end{array}$ & $\begin{array}{c}64 \\
4\end{array}$ & $\begin{array}{c}94.1 \\
5.9\end{array}$ & $\begin{array}{c}120 \\
5\end{array}$ & $\begin{array}{c}96.0 \\
4.0\end{array}$ & $0.55^{* *}$ \\
\hline $\mathrm{CRP}(\mathrm{mg} / \mathrm{dL})$ & Mean (SD) & 1.08 & 1.71 & 0.85 & 1.64 & $0.35^{*}$ \\
\hline Use of medication & & & & & & \\
\hline Gabapentine & $\begin{array}{l}\text { Yes } \\
\text { No }\end{array}$ & $\begin{array}{c}6 \\
62\end{array}$ & $\begin{array}{c}8.8 \\
91.2\end{array}$ & $\begin{array}{c}2 \\
125\end{array}$ & $\begin{array}{c}1.6 \\
98.4\end{array}$ & $0.02 * *$ \\
\hline Antihistamines & $\begin{array}{l}\text { Yes } \\
\text { No }\end{array}$ & $\begin{array}{l}46 \\
22\end{array}$ & $\begin{array}{l}67.6 \\
32.4\end{array}$ & $\begin{array}{l}50 \\
77\end{array}$ & $\begin{array}{l}39.4 \\
60.6\end{array}$ & $0.0001^{* *}$ \\
\hline
\end{tabular}

${ }^{*}$ T-test. ${ }^{* *}$ Chi squared. 
of antihistamines were associated with severe pruritus $(\mathrm{p}<0.05)$, defined as a score greater than or equal to 7 on the analog visual scale.

The results of the multivariate analysis are shown in Table 4, after adjusting for sex, age, time on hemodialysis, laboratory values and medication, it was established that hyperphosphatemia (PR 1.78, 95\% CI 1.13 - 2.79) and the use of antihistamines (PR $2.48,95 \%$ CI 1.56 - 3.94), were associated with a greater severity of pruritus. Contrariwise, a positive serology for Hepatitis C Virus (PR 0.55, 95\% CI 0.33 0.89 ) was determined to be a protective factor for severe itching.

\section{Discussion}

Because pruritus constitutes a frequent comorbidity in patients with terminal chronic kidney disease and how it impacts their quality of life, it is important to determine its prevalence in our population. While several studies indicate that the prevalence of pruritus ranges from 20 to
$90 \% ; 8,9$ in Peru, a previous study by Herrera-Añazco et al. estimated a prevalence of uremic pruritus in hemodialysis patients of $37.2 \%,{ }^{12}$ a number much lower than the one found in our investigation (73.9\%), besides, this also represents the first peruvian study that has managed to assess its severity. In that sense, the DOPPS study, the most extensive and important research in relation to uremic pruritus, not only due to the large number of patients included around the world, but also, in addition to reporting the prevalence of pruritus, had also categorized itching according to intensity, albeit using a Likert scale; according to their findings, the prevalence of "moderate to extreme" pruritus was $42 \%, 8,9$ a result very similar to ours.

Regarding the factors that are associated with the severity of pruritus, our multivariate analysis showed that hyperphosphatemia and the use of antihistamines were associated with the presence of severe itching. The relationship between the use of antihistamines and the presence of severe pruritus is expected, given that a more intense itching requires management beyond topical therapy, for example, the use of oral medications, including antihistamines, which according to some studies, have shown to reduce uremic pruritus and improve the quality of life. ${ }^{15}$ Nevertheless, that antihistaines are generally considered as ineffective in uremic itch and this could be a major reason, why patients having these medications suffered from more severe itch. Our study also found that hyperphosphatemia increases the prevalence of severe pruritus, which correlates to other investigations, as well as being part of the pathophysiology of chronic renal failure. ${ }^{8,9}$ Concerning comorbid hepatic infection, it has been described that patients on hemodialysis and peritoneal dialysis show a higher frequency of Hepatitis $\mathrm{C}$ infection rather than Hepatitis $\mathrm{B}$, nonetheless, both viruses are associated with a greater presence of moderate to severe pruritus compared to uninfected patients. ${ }^{9,16}$ It is known that pruritus in individuals infected with $\mathrm{HCV}$ is produced by virus-induced cholestasis, as well as an increase in chemokines (CCL2, CXCL1 and CXCL5) and cytokines (primarily IL8), both as a

Table 4. Crude and adjusted analysis between the characteristics and severity of pruritus in patients with end-stage renal disease.

\begin{tabular}{|c|c|c|c|c|c|}
\hline \multirow[t]{2}{*}{ Variables } & & \multicolumn{4}{|c|}{ Patients considered for multivariate analysis $(\mathrm{n}=195) *$} \\
\hline & & $\mathrm{PR}^{* *}(\mathrm{CI} 95 \%)$ & p & $\mathrm{PR}^{* * *}(\mathrm{CI} 95 \%)$ & p \\
\hline \multicolumn{6}{|c|}{ Characteristics of the participants } \\
\hline Age & (years) & $1.00(0.99-1.02)$ & 0.69 & $1.01(0.99-1.03)$ & 0.10 \\
\hline Gender & $\begin{array}{l}\text { Female } \\
\text { Male }\end{array}$ & $\begin{array}{c}\text { Ref } \\
1.19(0.79-1.81)\end{array}$ & $\begin{array}{l}\text { Ref } \\
0.39\end{array}$ & $\begin{array}{c}\text { Ref } \\
1.36(0.87-2.14)\end{array}$ & $\begin{array}{l}\text { Ref } \\
0.18\end{array}$ \\
\hline Hepatitis C serology & $\begin{array}{l}\text { No } \\
\text { Yes }\end{array}$ & $\begin{array}{c}\text { Ref } \\
0.55(0.33-0.89)\end{array}$ & $\begin{array}{c}\text { Ref } \\
0.008\end{array}$ & $\begin{array}{c}\text { Ref } \\
0.55(0.33-0.89)\end{array}$ & $\begin{array}{c}\text { Ref } \\
0.016\end{array}$ \\
\hline Dialysis time & (years) & $0.99(0.97-1.02)$ & 0.63 & $1.00(0.97-1.04)$ & 0.88 \\
\hline Dialysis dose & $\begin{array}{l}\mathrm{kt} / N \text { conventional } \\
\mathrm{kt} / \mathrm{l} \text { low }\end{array}$ & $\begin{array}{c}\text { Ref } \\
1.67(1.11-2.51)\end{array}$ & $\begin{array}{l}\text { Ref } \\
0.01\end{array}$ & $\begin{array}{c}\text { Ref } \\
1.18(0.69-2.01)\end{array}$ & $\begin{array}{l}\text { Ref } \\
0.55\end{array}$ \\
\hline \multicolumn{6}{|c|}{ Laboratory characteristics } \\
\hline Anemia & $\begin{array}{l}\text { No } \\
\text { Yes }\end{array}$ & $\begin{array}{c}\text { Ref } \\
0.92(0.57-1.47)\end{array}$ & $\begin{array}{l}\text { Ref } \\
0.72\end{array}$ & $\begin{array}{c}\text { Ref } \\
0.99(0.59-1.66)\end{array}$ & $\begin{array}{l}\text { Ref } \\
0.99\end{array}$ \\
\hline Hypercalcemia & $\begin{array}{l}\text { No } \\
\text { Yes }\end{array}$ & $\begin{array}{c}\text { Ref } \\
1.14(0.76-1.73)\end{array}$ & $\begin{array}{l}\text { Ref } \\
0.53\end{array}$ & $\begin{array}{c}\text { Ref } \\
1.02(0.70-1.51)\end{array}$ & $\begin{array}{l}\text { Ref } \\
0.88\end{array}$ \\
\hline Hyperphosphatemia & $\begin{array}{l}\text { No } \\
\text { Yes }\end{array}$ & $\begin{array}{c}\text { Ref } \\
1.69(1.17-2.46)\end{array}$ & $\begin{array}{c}\text { Ref } \\
0.006\end{array}$ & $\begin{array}{c}\text { Ref } \\
1.71(1.09-2.67)\end{array}$ & $\begin{array}{c}\text { Ref } \\
0.018\end{array}$ \\
\hline Hypoalbuminemia & $\begin{array}{l}\text { No } \\
\text { Yes }\end{array}$ & $\begin{array}{c}\text { Ref } \\
0.98(0.66-1.46)\end{array}$ & $\begin{array}{l}\text { Ref } \\
0.92\end{array}$ & $\begin{array}{c}\text { Ref } \\
1.09(0.69-1.69)\end{array}$ & $\begin{array}{l}\text { Ref } \\
0.71\end{array}$ \\
\hline Excess of Ferritin & $\begin{array}{l}\text { No } \\
\text { Yes }\end{array}$ & $\begin{array}{c}\text { Ref } \\
0.78(0.37-1.67)\end{array}$ & $\begin{array}{l}\text { Ref } \\
0.53\end{array}$ & $\begin{array}{c}\text { Ref } \\
0.81(0.41-1.61)\end{array}$ & $\begin{array}{l}\text { Ref } \\
0.71\end{array}$ \\
\hline $\mathrm{CRP}$ & $(\mathrm{mg} / \mathrm{dL})$ & $1.05(0.96-1.14)$ & 0.32 & $0.95(0.78-1.15)$ & 0.58 \\
\hline \multicolumn{6}{|l|}{ Use of medications } \\
\hline Gabapentin & $\begin{array}{l}\text { No } \\
\text { Yes }\end{array}$ & $\begin{array}{c}\text { Ref } \\
2.26(1.44-3.55)\end{array}$ & $\begin{array}{c}\text { Ref } \\
0.0001\end{array}$ & $\begin{array}{c}\text { Ref } \\
1.36(0.79-2.32)\end{array}$ & $\begin{array}{l}\text { Ref } \\
0.26\end{array}$ \\
\hline Antihistamines & $\begin{array}{l}\text { No } \\
\text { Yes }\end{array}$ & $\begin{array}{c}\text { Ref } \\
2.16(1.41-3.29)\end{array}$ & $\begin{array}{c}\text { Ref } \\
0.0001\end{array}$ & $\begin{array}{c}\text { Ref } \\
2.39(1.51-3.79)\end{array}$ & $\begin{array}{c}\text { Ref } \\
0.0001\end{array}$ \\
\hline
\end{tabular}

* Poisson regression analysis with robust error variance. ${ }^{* *}(\mathrm{n}=195)$ crude. ${ }^{* * *}(\mathrm{n}=178)$ adjusted. 
result of high viral counts, which constitutes an active $\mathrm{HCV}$ infection. ${ }^{17-20}$ In contrast to what is described above, our study determines that a positive serology for $\mathrm{HCV}$ is a protective factor for the development of severe pruritus. This suggests that it is not enough to describe a positive serological result, but rather to determine disease activity by measuring viral load.

We did not find an association between severe pruritus and risk factors such as hypercalcemia, hypoalbuminemia, anemia, the presence of pro-inflammatory markers such as CRP, among others. ${ }^{10,11,21}$ More recent studies have included other variables, for example, a high white blood cell count or the presence of xerosis. ${ }^{22}$ In 2019 Ersoy and Akyar found a higher pruritus severity score both in patients over 65 years and those in hemodialysis for 15 years or more. ${ }^{23}$ These results differ from the findings of our study where no association was found between the severity of itching and the patient's mean time in hemodialysis.

In conclusion, pruritus is a common phenomenon in patients with terminal chronic kidney disease; its severity is associated with a significant and progressive deterioration in the quality of life of patients undergoing hemodialysis. This study demonstrates the magnitude of the problem in the patients of the Centro Nacional de Salud Renal (CNSR) and encourage the need for interdisciplinary management between nephrologists and dermatologists to prevent and treat it.

\section{Scope and limitations}

In addition to reporting the prevalence and severity of uremic pruritus in patients with terminal chronic kidney disease, it is also important to define its impact on the quality of life of the patients. Many studies have attempted to answer this question, using a series of surveys that are difficult to apply in daily practice. However, recently a new 27-item questionnaire has been designed, the UP-Dial, which assesses uremic pruritus in all its dimensions (23). As a continuation of this investigation, this new tool could be validated in the previously studied population. Likewise, it would be interesting to make a comparison between hemodialysis and peritoneal dialysis.

This study has some limitations. First, because it is a cross-sectional study, a causal relationship between the variables studied cannot be established. Likewise, it was not possible to analyze some factors associated with severe uremic pruritus, which could have enriched the analysis.

\section{References}

1. Jha V, Garcia-Garcia G, Iseki K, et al. Chronic kidney disease: global dimension and perspectives. Lancet 2013;382: 260-72.

2. Anees M, Butt G, Gull S, et al. Factors affecting dermatological manifestations in patients with end stage renal disease. J Coll Physicians Surg Pak 2018;28:98102.

3. White SL, Chadban SJ, Jan S, et al. How can we achieve global equity in provision of renal replacement therapy? Bull World Health Organ 2008;86:22937.

4. Fleischer AB. The Clinical Management of Itching. New York, USA: Parthenon, 2000. pp 210.

5. Greaves MW, Khalifa N. Itch: more than skin deep. Int Arch Allergy Immunol 2004;135:166-72.

6. Akhyani M, Ganji MR, Samadi N, et al M. Pruritus in hemodyalisis patients. BMC Dermatology 2005;5:1-6.

7. Yosipovitch G., Greaves M.W., Schmelz M. Itch. Lancet. 2003;361: 690-4.

8. Pisoni RL, Wikstrom B, Elder SJ, et al. Pruritus in haemodialysis patients: international results from the dialysis outcomes and practice patterns study (DOPPS). Nephrol Dial Transplant 2006;21:3495-505.

9. Attia E, Hassan AA. Uremic pruritus pathogenesis, Revisited. Arab Journal of Nephrology and Transplantation 2014;7:91-6.

10. Aucella F, Vigilante M, Gesuete A. Review: the effect of polymethylmethacrylate dialysis membranes on uraemic pruritus. NDT Plus 2010;3:i8i11 doi: 10.1093/ndtplus/sfq031

11. Ko MJ, Peng YS, Chen HY, et al. Interleukin-31 is associated with uremic pruritus in patients receiving hemodialysis. J Am Acad Dermatol 2014;71:1151-9.

12. Herrera-Añazco $P$, Hurtado-Aréstegui A, Bonilla-Vargas L, et al. Pruritus in hemodialysis patients. Rev Soc Peru Med Interna 2011;24:66-70.

13. Centro Nacional de Salud Renal. Informe del registro nacional de diálisis (RENDES)-EsSalud 2015. Lima: EsSalud - Centro Nacional de Salud Renal, 2017.

14. Reich A, Heisig M, Phan NQ, et al. Visual analogue scale: Evaluation of the instrument for the assessment of pruritus. Acta Derm Venereol 2012;92:497501

15. Gobo-Oliveira M, Pigari VG, Ogata MS, et al. Gabapentin versus dexchlorpheniramine as treatment for uremic pruritus: a randomized controlled trial. Eur J Dermatol 2018;28:488-95.

16. Hung KY, Shyu RS, Tsai TJ, Chen WY. Viral hepatitis infection should be considered for evaluating uremic pruritus in continuous ambulatory peritoneal dialysis patients. Blood Purif 1998;16:14753.

17. Villaverde AF, Benlloch S, Berenguer $\mathrm{M}$, et al. Acute hepatitis of cholestatic type possibly associated with the use of glucomannan (amorphophalus konjac). J Hepatol 2004;41:1061-2.

18. Deshpande V, Burd E, Aardema KL, et al. High levels of hepatitis $C$ virus RNA in native livers correlate with the development of cholestatic hepatitis in liver allografts and a poor outcome. Liver Transpl 2001;7:118-24.

19. Alhmada Y, Selimovic D, Murad F, et al. Hepatitis $\mathrm{C}$ virus-associated pruritus: etiopathogenesis and therapeutic strategies. World J Gastroenterol. 2017;23: 743-50.

20. Shirazian S, Kline M, Sakhiya V, et al. Longitudinal predictors of uremic pruritus. J Ren Nutr. 2013;23:428-31.

21. Ozen N, Cinar FI, Askin D, Mut D. Uremic pruritus and associated factors in hemodialysis patients: A multi-center study. Kidney Res Clin Pract. 2018;37: 138-47.

22. Esroy NA, Akyar İ. Multidimensional pruritus assessment in hemodialysis patients. BMC Nephrol. 2019;20:42.

23. Nochaiwong S, Ruengorn C, Awiphan $\mathrm{R}$, et al. Development of a multidimensional assessment tool for uraemic pruritus: Uraemic Pruritus in Dialysis Patients (UP-Dial). Br J Dermatol 2017;176:1516-5. 